\title{
"We want to speak for ourselves ...!" The agenda of African initiated churches on decolonised and transformative theological education in Southern Africa
}

\section{Tobias Masuku ${ }^{1}$}

\begin{abstract}
"Viva, away with colonised education away...!" This slogan and others similar to it became common in South Africa recently. Protest marches were seen at tertiary institutions crying out loud against what is called a colonised education and curriculum. Debates from various academic spaces were triggered in search for what could be a decolonised education in Africa, South Africa in particular. There was a need for a decolonised education based on a relevant curriculum as a solution to the problem at hand. Theological education is not immune to this problem because it is also a product of the apartheid and colonial project. The answer to the question as to what is a relevant theological education today, that is decolonised based on a 'peoples' curriculum still stands unanswered. This article seeks to present a contribution from the ignored or rather despised voices on this debate, the African Initiated Churches. It proposes a solution from the African Initiated Churches' perspective where they speak by themselves, hence the title of this article; "We want to speak for ourselves...!" The author regards the African Initiated Churches as "church groups related to colonial resistance" (Molobi 2000:11).

Thus, the author will approach this project by outlining the background information in investigating who the African Initiated Churches are, the reasons for their birth, etc. He will further investigate their ecclesiology, theology and ecumenical mission praxis. The position of women and the youth will also be embraced. On ecumenism, focus will be on African Initiated Church bodies like the Organisation of African Initiated Churches though their ecumenical partners will be acknowledged. The African Initiated Church position on social justice as a means of understanding the strength behind their anti-colonial drive will also be addressed. The article will also outline debate on theological education. In the end, a relevant theological education curriculum will be proposed from the voices of the African Initiated Churches as gathered in this article.
\end{abstract}

Keywords: African Initiated Churches, theological education, curriculum, decolonised education, OAIC, decolonisation

1 Dr Tobias Masuku is a Researcher in the Institute for Theology and Religion at UNISA. He is also a Research Associate at the University of Pretoria. He can be contacted at masukumt@penta-net.co.za 


\section{Introduction}

In one of his writings on theological education from African Initiated Churches (AICs) perspective, Masuku (1996:392) argued;

The AICs represent a forgotten voice in most of the theological debates including those that affect them directly like the subject on theological education. My thesis is that most of the theological debates that exclude the views of the AICs are not complete, since the AICs constitute a majority group within the Christian community in South Africa. In the debate on theological education in the past, contributions were made from different angles but the voice of the AICs had never been listened to.

There are many examples of this exclusion, for instance, de Gruchy (1996:10; Masuku, 1998:392) refers to a report where they were excluded at the African Consultation on the Viability of Ecumenical Theological Formation held in Moffat Mission in Kuruman 1-6 August 1995. Views were invited from all parts of Africa but excluded the AICs.

The friction between AICs and historic churches is well documented (Mala, 1991:22,34; Daneel, 1987:9; Sundkler, 1948:297). As an indication of this negative relationship, Nongogo (1999:54) calls the historic churches "foreign church". Ngada (1999:1) acknowledges that they were abused and called derogatory names by the historic churches. Chakanza (1991:126) is therefore correct in saying that when one compares the Christian divisions in Europe and America with the Christian divisions in Africa, the main divide is no longer between Rome and Reformation but AICs and historic churches. The AICs are being accused of distorting the Christian faith because of their so-called inferior or no theological education (Mala, 1991:30-31; Dlamini, 1991:129). The author argues that theological education is at the centre of this tension, thus education can also build relationships. That is why he joins Saayman (2013:133) when he looks at theological education as another dimension for mission, thus coining it as; "Mission as theological education." He drove this point through a case study of the ecumenical cooperation in missiological education between the University of South Africa (UNISA) and Gesellschaft fur Bildung und Forschung in Europa (GBFE) that originated from Russian-born ethnic Germans in Germany (in 1999 when a contract was officially signed). If these two institutions constructed a relationship that grew so much today, on the grounds of theological education, the same could be applied between the historic churches and the AICs when also brought together within the sphere of theological education. Thus, mission as theological education can play an important role as it will allow the voice of the AICs to be listened to, and learn something out of their experience and struggle. 
The AICs want to do things themselves without assistance or approval from the West or global north. They also want to present their case to have their voice heard not others doing it for them. Molobi (2011) is therefore on point when he echoed; "The AICs have been concerned that no one should speak for them without their consent. They have a valid concern that interpreters, translators and their representatives write honestly about them". They want to speak for themselves, hence the title of this article; "We want to speak for ourselves...!" as uttered by two prominent AIC leaders, Archbishop Ngada and Bishop Mofokeng (2001:18). Therefore, in line with this article title, the author's primary interlocutors would be the AICs and his secondary interlocutors will be the 'accredited' AICs' 'spokespersons,' that means, scholars outside the AICs' camp who researched on them. The latter will be drawn from both etic and emic camps of approach in the author's quest for a relevant, decolonised and transformative theological education in Southern Africa. This means that the AICs will be the protagonists in this debate within the scope of this article. Attempt has been made to consult the biggest possible number of representatives of the AICs voice. Consultation has therefore been made with AICs strong voices from what Molobi (2013) termed "the fathers of this movement".

The author will be parading this term, 'decolonisation' hence decolonised theological education because he believes that a theological education to be effectively transformative in Africa needs to be preceded by total decolonisation. Although some scholars employ both terms namely; 'decolonisation' and 'transformation' interchangeably, the author wishes to argue that the former goes deeper than the latter. The author understands though that decolonisation does not guarantee the total elimination of the negative effects of the colonial matrix of power or coloniality. Decolonisation calls for theological education in Africa to grow from the seed not be transformed as a transplant of a theological seminary, transplanted from the global north, but the natural growth of an African social, political systems and epistemologies. It also calls for change of attitude or decolonisation of the minds of theological educators. The AICs fit well into this framework because they seek to grow Christianity in Africa from the seed not to transform the transplanted one from the West hence their name, African 'initiated' or 'independent' from Western Christian epistemological tradition. The fact that the AICs grow faster than the historic churches in Africa (Pobee \& Ositelu, 1998:5; Shank, 1991:4-5; Ngada \& Mofokeng, 2001:xi), and that they are making inroads into Europe (Pobee \& Ositelu, 1998:52), demonstrates the transformative capability and success of their mission praxis.

In allowing one selves to listen to the AICs' plan in this article, the author found Maluleke (1994:13) singing from the same hymn-book when he argued; "Ordinary people, as well as students, should be involved even if they do not have sophisticat- 
ed degrees in theology. People may not know what and how to teach, but they know what to be equipped with". From AICs' perspective, Pobee and Ositelu (1998:3) correctly warned as follows; "Anyone who dares to write about another denomination or religion must bear in mind the simple truth that it is a believer and participant of a tradition who is best able to understand and articulate that tradition".

In the end, this article seeks to develop and present an AICs' transformative theological education strategy as a solution. At the same time the author will argue that theological education should recognise global emerging various theologies. Any theology that is using the Bible and proves itself to be scriptural in its ethics should be recognised. The author argues, by letting the AICs to speak for themselves, that one should not use the Western theology, theological education in this regard, which is deemed to be the cause for all the trouble because of its colonised colorings, as a yard stick or model for theological education, for all contexts including Africa and Southern Africa in particular (Kealotswe, 2013:439).

\section{Who are the AICs?}

In order to better understand the AICs' position, the author joins Kealotswe (2013:437), who when writing about the relevant theological education for the AICs in Botswana, stressed the need for understanding who they are as a prerequisite. AICs are basically those churches that broke away or were expelled from the historic churches because of administrative or doctrinal differences. For instance, Pobee and Ositelu (1998:2; Oduro, 2013:425) indicate that the Christ Apostolic Church of Nigeria was formed by a group that broke away from the Anglican Church on doctrinal differences. Some were expelled from the historic churches not broke away e.g., the Church of the Lord (Aladura) because of the Pentecostal element which the Church Missionary Society (Anglican) could not bear. Makhubu (1999:15) come out with a more acceptable definition that AICs are churches founded in the African continent by Africans for mainly Africans. He sees them as representing the search for an African identity of the church (Ibid., 16). Molisiwa (1999:47) predicted that the AICs are the future church of Africa. The story of the AIC called Corinthian Church of South Africa (CCSA) founded by Bishop Johannes Richmond stands up as a case study to indicate that these churches were born as a response to the felt needs of the African people (Wepener, 2015:7).

The birth of the AICs was a reaction as a means of decolonising Christianity in Africa. They were responding from African perspective, to the North Atlantic captivity of the church in Africa. In the mind of Pobee and Ositelu (1998:1), they demonstrated discontentment with Western church structures, patterns of ministry, liturgical forms, hymnody and architectural buildings that were imported by Western Christian Missionaries to Africa. According to Hollenweger (Pobee \& Ositelu, 
1998:ix), they refused to operate according to the Anglo-Saxon parliamentary system that is characterised by strong leadership chosen democratically in a church assembly like synod, etc.

The acronym AICs stand for the African Independent Churches. The "I" in the middle also stands for Initiated, Indigenous or Instituted (Pobee \& Ositelu, 1998: 3). Makofane (2019:138; cf. Padwick, 2018:17) presented another better option that "it is common to call these churches 'African Independent', African Initiated', 'African Instituted', or 'African Indigenous' Churches”. Molisiwa (1999:47) touched on this point when he echoed; "We are known by many names; African Independent Churches, African Indigenous Churches, African Traditional Churches and African Initiated Churches". Despite this, the apartheid regime called them separatisme (Afrikaans language for separatism) as an overarching title of all these groups (Muller, 2017:1). All these terms bear the same message of churches that refused to be influenced by colonial Christianity. From this list, the author elected 'Initiated' hence African Initiated Churches (AICs) in this article. This acronym, AICs, distinguishes them from mission, historic, mainline, or established churches (ibid., 3). From this list, the author chose to employ "historic" hence "historic churches" in this article for reasons of consistency.

AICs embrace three typologies viz; Ethiopian (non-prophetic), Prophetic (Spirit-type), and Messianic churches (Daneel, 2000:vii; Daneel, 1987:38-4; Ngada \& Mofokeng, 2001:19). Oduro (2013:423) formulated his own distinct typology viz; Conservative AICs (classical AICs), Reformed AICs and Charismatic AICs. In this paper, the author adopted the first category of typology.

The argument here is that the AICs take the matter of decolonisation very serious. They were among the first to act against the Western influence in African religious sphere of life. Ngada and Mofokeng (2001:4) confirmed that the first AIC in South Africa was formed in 1884. It came as a result of a breakaway that was experienced in the Methodist Church. This action conceived the first AIC which was named the Thembu National Church. The AICs developed the Africanised version of Christianity that came to run parallel to that of the historic churches. It was along these lines that Mijoga (2000), looking at the situation in Malawi, entitled his book; Separate but same Gospel. Shank (1991) entitled the book he edited about the AICs as; Ministry in partnership with African Independent Churches. A friction between these two Christian streams developed. This led Masuku (1996) to entitle his article as; African Initiated Churches: Christian Partners or Antagonist? AICs can, therefore, play a meaningful role in the current debate, when judged by the quality of their fight against colonial domination.

Daneel (1987:129) correctly summarised the credentials of the AICs as fighters against colonisation of Christianity as follows; 
the most common cause for conflict and polarization is the Independent Churches' Independence, not only at the religious but also at the party political level, and their refusal to be manipulated by either political pressure groups or biased political servants.

AICs are, therefore, protest religious movements, protesting against Western colonisation of the Gospel and other spheres of life. They are according to Moodley (2008:58), a response by Africans to the necessity of indigenising the gospel to an extent that it addresses the needs of their followers. In the words of Milumba (2016:14), they wanted to be "relevant to the contextual needs".

\section{The ecclesiology, theology and ecumenical mission praxis of the AICs}

The ecclesiology of the AICs has been a center for debate in academic circles. The Organisation of African Initiated Churches (OAIC) founded in 1975 with head quarters in Nairobi, Kenya defined the church as "a movement of the people of God called by Him and empowered by His Spirit to undertake the new initiatives, especially in building ubuntu (Shalom), a human society without poverty, exploitation or disease" (Molobi, 2013). This body had to articulate and communicate the AICs' vision of the human community of God throughout the African continent and globally. In the light of this understanding, is Sundkler correct in questioning their ecclesiological character (Daneel, 1987:9; Sundkler, 1948:297)? The use of the term 'church' is correct because their leaders see themselves as churches of Christ. Daneel (1987:31) adds his voice by applying an emic approach when he reasons that they are churches. There is a manifestation of notae ecclesiae in these churches. Moral standards are, however, adapted to tribal law and traditional codes of conduct. The theological evaluation could be left with individual group. Daneel (ibid., 269) further warns that unfortunately, what could be seen by mission churches as poor theological training, might have barred them to come up with a clear historical perspective on the development of the church through the ages. Thus, the indigenous culture and social structure left the mark in AICs ecclesiology. In their application of the etic approach, Martin and Oosthuizen (Daneel, 1987:270) stated that the church was therefore seen as a new tribal community with new codes of conduct.

Pobee and Ositelu (1998:40) responding for the AICs stated; "AICs also claim to be Christian and church, and thus to belong to the 'one holy, catholic and apostolic church' and the one household of God. They may be quite different from the mission-founded or historic churches. But as part of the household of God they have ecumenical significance". They further added that in speaking of two African 
churches, namely; the AICs and historic churches, both categories claim first to be Christian and secondly to belong to the one church of Christ. They conclude this by saying that these two groups indicate the diversity and divergence within the 'one holy, catholic and apostolic church.' The AICs urge historic churches to desist from indiscriminately applying their own perspective notae ecclesiae to others. They also advised that the search for further criteria for measuring AICs should include; the role of the church in society, incarnational theology and perception of salvation (ibid., 6-7).

The AICs pride themselves as leading the mainline churches in a number of areas including gender and youth ministries. Ngada \& Mofokeng (2001:47) indicated that, unlike in the main line churches, the AICs do not discriminate against women when coming to leadership. For instance, Lydia August of the St John's Apostolic Faith Mission was the assistant chairperson of the OAIC Southern Africa Region, and the Secretary of the national AIC (Molobi 2006). They acknowledge that women are in the majority in churches and they are therefore part of the top leadership structures. The AICs also made space for the youth. They allowed them to form their own structures and activities in line with the constitutions of each AIC (Ibid., 48).

Missional element of the AICs is seen from the fact that they are not only transformative in Africa but also in Europe. For instance, they established themselves in Amsterdam, London, and Birmingham, Hamburg, Geneva and Zurich. About 20 congregations are found in the Netherlands. They attracted Dutch converts in areas where historic churches are losing ground. They are therefore becoming international, ecumenical and missional (Pobee \& Ositelo, 1998: 52).

In light of this, the AICs are in line with calls by Mulemfo (1997:101) of "An African missionary in return!" or Reimer (2007:3) who in referring to calls like these, coined concepts such as "Mission reversed" (ibid., 4) or "The Gospel in return?" (ibid., 8). Saayman (2013:137) referred to this trend as a "Christian mission coming full circle". Calls such as "missionary go home!" (Masuku, 1998:47; Pederson, 1980), emanated from a similar situation of Western influence on Christianity in Africa. According to Makofane (2019: 127), the AICs stand out as a model towards the historic churches, on how to live up to the challenges posed by the moratorium debate whereby he used the Evangelical Lutheran Church of Southern Africa as a case study.

The theology of the AICs is well spelt out in the vision of the OAIC. In their consultation held in December 2009, AICs considered themselves as "the people of God who built on their African cultures and values, transformed by the biblical truth and the Holy Spirit to create an abundant life in the community for their children and the world" (Molobi 2013). This theology emphasised the power of the gospel to continuously transform people, theologies and churches thus ensuring that the 
challenge of the gospel remains fresh and focused on contemporary realities that affect their members (Ibid.). Ngada and Mofokeng (2001:23) emphasise the centrality of the Holy Spirit in the theology of the AICs. The Holy Spirit is seen as playing a pivotal role although there is a clarification that there are spirits of various kinds. AICs believe that they found in the Bible the same cultural beliefs they held in the world of the spirits. In this way, they hold that African culture prepared them to accept the Bible. Jesus belongs to all races and is, "the heart and soul of the Bible" (Ibid., 28). Molobi (2010) sees the theology of the AICs in some areas being on par with other theologies such as Black Theology and African Theology "on liberation, of an autonomous and truly African Church, a Christ who was at home among Africans and vibrant and meaningful African culture". Molobi (2011) is therefore correct in summarising the definition of the theology of the AICs thus;

The African Instituted Churches form an integral part of world Christian communions. Consequently, the AICs share in the common theologies of Christianity. The AICs believe in the revelation of God, the Trinity, the Atonement, the humanity and deity of Jesus Christ, the vicarious death of Jesus Christ, the resurrection, ascension and second coming of Jesus Christ, and many other prominent tenets of Christianity.

The AICs are also concerned about inter-AICs relations together with other church organisations such as the World Council of Churches (WCC). Tshelane (1999:29) emphasised the importance for structure and unity as the main concern of the AICs. This stands high on their agenda in any gathering. The OAIC was an ecumenical tool for the AICs. The aim of this body was;

to provide a forum for AIC leaders to fellowship and share their concerns. The OAIC also sought to provide a better theological and biblical education for its members, including the promotion of Sunday Schools. The OAIC was thus an institutional expression of the movement, vision and aspiration of the AICs. One of its basic aims was to promote teaching and training among the AICs (Molobi, 2012).

This body stood on par alongside other ecumenical bodies of world churches such as WCC. It became apparent that apart from building unity of the AICs across the African continent, it stood for their interest on all fronts. Milumba (2016:18) captured the objective of the OAIC well thus: "to provide a forum for unity, and to share concerns, and also learn from one another through dialogue". The ecumenical drive of the AICs could also be seen from the partnerships the OAIC has with other world ecumenical bodies. The examples of these are the WCC, Global Christian Forum, All Africa Council of Churches and the World Conference on Religion for Peace (Molobi, 2011). 
Bodies that attempted to bring them together in South Africa were African Spiritual Churches Association (ASCA), though it was not exclusively for Spirit type churches. There was also the African Independent Churches Association (AICA) in the early 70s which at one stage had 460 AICs together and they put on top of their agenda, the theological seminary for the AICs. The AICs were also ecumenically brought together by theological training institutions like South African Theological College of Independent Churches (SATCIC). When this college collapsed in 1977, Theological Education by Extension (TEE) took over their programme (Ngada \& Mofokeng, 2001:20). In the late 70s, another attempt made was the Council of African Independent Churches (CAIC). Top on her agenda was to build relations with the South African Council of Churches (SACC). CAIC was an umbrella body for all AICs associations (Ibid., 21). Another body that also tried to bring together a number of associations that was launched in 1992 was called the Federal Council of the Indigenous Churches of South Africa (FEDCAIC) (ibid., 22). AICs are now represented in SACC and WCC. In Zimbabwe, the Fambidzano project also made strides in bringing the AICs together.

\section{AICs and social justice}

The AICs possess uncontested credentials in the fight against colonial powers and structures in both church and society. These credentials will enable one to understand the background of their strides in the fight against colonial theological education. It is along these lines that Makhubu (1999:12) located the church in society, as part of the realities of the world. Molisiwa (1999:51) visualizes ecumenical AICs that could fight corruption in Africa. He said that they would be able to set example of speaking against poverty and exploitation of the African people. Molobi (2013) indicates the agenda of the OAIC as also focusing on social justice. Improvement of the lives and opportunities of the rural and urban poor as well as strengthening food security of the rural and urban poor were highlighted.

AICs are products of colonial Christian ethos. Nongogo (1999:53) echoed that they are a result of severe discrimination by the missionary churches, colonial and apartheid regime. In the early stages of their development, they played a leading role in the awakening of black nationalists' movements. They did this by addressing themselves to the political grievances of Black under White rule. They are the early warning or sign of dissatisfaction with the white domination of churches and other spheres of life in South Africa. The AICs compensated for the loss of self-determination and acted as a space for dissatisfaction and grievances. During the earlier stages of these churches, there was a close relationship between them and the black nationalists' movements because of their Black membership on both sides. The leadership of the nationalist movements was Christians and depended on Christian 
leadership. Moremi (1991:57) was therefore correct to indicate that the president of ANC in 1924 was Rev. Z. Malebane. AICs were also attractive to the Africanist Pan African Congress (PAC). It was, therefore, no surprise that the first convention of PAC in 1959 was opened with a sermon and prayer from an AIC leader, Bishop Dimpa, head of the Federation of Bantu Churches in South Africa.

AICs address the hopes and fears of the Africans. They address matters of witchcraft and exorcism and offer help in areas of racism and political oppression. According to Arch Bishop John M Kivuli II (ibid., 27), the reasons for the birth of the AICs were political, sociological, economic, and also physical. AICs play varied socio-political, economic and religious roles in rural and urban environments. They represent a quest for African people for a place to feel at home and where they have a sense of belonging (ibid., 35). Moremi (1991:61) is therefore correct in saying that: "Wherever possible, the AICs have always initiated and maintained the various social and economic enterprises of the people in agriculture, housing and home industries".

The AICs had been in conflict with colonial authorities. The year 1915 saw the rebellion of John Chilembwe in Nyasaland. In 1918-1919 there was unrest as a result of the prophets of Watch Tower which saw the Whites in the then Northern Rhodesia becoming slaves of the Blacks. This brought fear to the SA apartheid government which two years later, in 1921 hit hard on the 'Israelites' when their leader refused to move out of the government property (plot) in Bulhoek. This led to the so-called Bulhoek massacre in which more than a hundred people were killed. In 1925, the prophetic movement of Kimbangu was suppressed because they were seen as a threat by the colonial regime, as a result of the prejudice caused by the reports of the Catholic priests to the colonial regime. Of note is also the conflict between Alice Lenshina's Lumpa church and the Zambia newly independent government of UNIP because she did not offer unconditional support to it (Daneel, 1987:128; Pobee \& Ositelu, 1998:46). Daneel (Ibid.,129) parades the Zimbabwean situation which bears same characteristics of opposition against colonial ethos. In his narrative, the resistance by Shona churches and others through their prophetic voice to national and party politics was clear

\section{Scanning the debate on theological education}

The definition of theological education has never been easy. This was also noticed by Theron (1993:51) who when referring to this matter reasoned that it is impossible to answer this question in a few words because different people will have different answers. In some circles within academia, theological education is confused with religious education. Answers given regarding theological education are also applied to religious education. For instance, the fact that it is difficult to define 
theological education is also applied to religious education. That is why Burgess (1975:1) in trying to answer the question on the meaning of religious education, applied the same principle thus; “...those who write journal articles and author of statements in denominational handbooks, are not able to give a satisfactory answer to the question "what is religious education?"

Curriculum for theological education also stands out as a debatable matter. The question on the required number of subjects and their content stands out as an issue that seeks answers. Should the curriculum include what Qgubule (Richardson, 2007:135) calls 'general education', meaning academic and non-theological subjects? Others like Neill (1954:59ff) propose four subjects for theological education. The context becomes an issue. Theron (1993:80) reasons that theological education should accommodate the different contexts in which it finds itself. Maluleke (1994:10) suggests the adoption of the specific theological framework but at the same time acknowledges that the framework stands a risk of being betrayed by the demarcation of fields and subjects. However, Cochrane (1996:4) pleads for the following areas to be considered for addition in the theological curriculum: gender, racism, leadership role of the church in society, the changed nature of leadership and culture.

What should be the ideal qualification for theological educators? This issue constitutes another angle on this debate. According to Neill (1954:55), "spirit and personality in full Christian implications" are the basic qualifications. He adds that this should be empowered by a university education or equivalent to cultural interests. The medium of instruction for theological educators stands out as another element of this debate. There are problems in the lack of literature in any one African language and the multiplicity of languages in a particular school (Neill, 1954:74). In this situation, English is used as an option. The importance of using the vernacular has also been echoed by Theron (1993:71ff). He warned of the application of an authentic contextualisation and emphasised the importance of using vernacular. He laments the fact that most of the theological education today in Africa is done in one of the foreign languages, French, English or Portuguese. Maluleke (1994:13) in his article published in 1994 lamented the fact that theological education is taught either in English or Afrikaans and that this practice disadvantaged the Black students. He touched on the serious strategic outcome of this being the potential of removing religion from African languages, and further warned that a language that cannot 'speak' religion is literally a dead language.

The position of women in theological education stands out as another side of debate on theological education. It has been noted that women are ignored in Africa in teaching programmes. Limitations placed upon them by African society are deemed to be responsible. Neill (1954:53ff.) observed that women are play- 
ing a very important role in the churches as deaconesses, youth workers, Sunday school teachers, etc. The same situation was noted in Kenya by Ekeya (1990:87). In Maluleke's (1994:9) view, the phrase "theological education" conventionally refers to the training of mainly male candidates for ordained ministry.

\section{Towards a relevant theological education and curriculum}

Do AICs look at theological education in a serious light? Historic churches blame them for not being theologically sound, this, therefore, deviates them from the true faith. Theological education initiatives by AICs were seen in a number of ways. The OAIC (Padwick, 2018:15) had a special focus on the development of the theological education and training of their member churches. Makhubu (1999:22) defined the importance of theological education for the AICs well when he said that it stands for the development of the mind. This includes leadership in order to stand in a good position to enter into dialogue with the world. The zeal for theological education among the AICs was already noticed in 1965 when they even approached the multi-racial and interdenominational Christian Institute (CI) (Ngada \& Mofokeng, 2001:vii). An AIC leader, Bishop Makhubu (1991:269) is therefore correct when he said; "AICs have always responded to all kinds of theological offers because of the need and hunger of wanting knowledge and skills in leading their churches. Times are changing and the leadership is challenged if not threatened by events and a younger emerging leadership". The contribution by St. John's Apostolic Faith Mission on education in general, where three primary schools were built and an education bursary fund named after one of the leaders of this church in honour of her role in this project, demonstrates another dimension of the AICs' seriousness on education and theological one in particular (Molobi, 2006). Bishop M.H. Ngobeni (Masuku, 1998:404) an AIC leader in the African United Ethiopian Church, boasts of having a Bible certificate and asks; "what can one teach in church if not educated? A minister should spend five years at theological training". The zeal for education was also seen from the comments of some AIC leaders on matters of gender with regards to educators of theological education. For instance, Rev. S.W. More (Masuku, 1998:408) of the African Church and Bishop P. Mashiloane (Ibid.,) of the Church of Christ Holy Spirit Amajuba, hold the view that educated women can make a difference in theological education (Ibid.,). Today, members of the AICs form part the theological student community of the University of Pretoria (De Beer \& Van Niekerk, 2017:218).

In Zimbabwe, the AICs had Fambidzano which administered Theological Education by Extension (TEE). The AICs in Ghana had Good News Institute as a body that facilitated their theological education. The Church of the Lord (Aladura) in Nigeria owned a seminary. The Kimbaguist Church had a theological programme and the 
theological faculty for the purpose of training. The AICs' quest for theological education pushed them to forge contact with the WCC wing on theological education (Pobee \& Ositelu, 1998:58-59). Previously, AIC leaders would claim that they are from the 'university' of the Holy Spirit but later as had been seen above, they appreciated the value of theological education (ibid., 59).

African Independent Church Association (AICA) became a platform for AICs development in theological education. It was through AICA that funds were raised with the aim of building their own theological seminary. A correspondence course was also considered by AICA. AICA saw the need and importance of theological education for their ministers. Due to the financial challenge that prevented them from erecting their own building, they sent their candidates to any theological institution that can accept them. The African Methodist Episcopal Church (AME) accepted the AICs' candidates in 1967 (Ngada \& Mofokeng, 2001:19-20).

Three years later AICA rented a building in Alice but sadly against their wish, due to being taught by lecturers from the historic churches, it did not last. AICA's seriousness on AICs' theological education, saw them renting part of St. Peter's Seminary in Hammanskraal with the correspondence course fully functional as set up by the CI. Cooperation among AICs was materialised by this combined training. This training, unfortunately, closed in 1973 due to differences in funds within the AICs leadership (Ngada \& Mofokeng, 2001:20). Later on with the assistance of SACC the South African Theological College of Independent Churches (SATCIC) was formed in Roodepoort but was short-lived as it also closed. The correspondence course was swallowed by Theological Education by Extension College (TEE) and lost AICs identity and ownership (Ibid., 20).

Theological reflection at grassroots level was encouraged. Thus an AICs association called African Spiritual Churches Association (ASCA) in collaboration with ICT set up a programme that enabled AICs to train their own ministers from their own theological point of view. It was called Spiritual Churches Research and Theological Training Institute (SCRTTI). The method of their training emphasised learning together thus relying on workshops and discussions than reading. Correspondence courses were also developed. A sense of unity amongst the AICs was developed by this training method. This unity was seen in the establishment of an umbrella body bringing all AICs together which was called Federal Council of African Indigenous Churches (FEDCAIC) in June 1991 in Soweto, Johannesburg (Ngada \& Mofokeng, 2001:22).

Other efforts towards the training of the AICs were seen as follows; AICA started a theological school with the help of CI. In Zimbabwe, the theological training centre of Fambidzano successfully provided an extension training programme. Many Shona AIC candidates completed the two-year course. At some stage, this programme was 
run by fifteen Shona lecturers, mainly Zionists who were trained at Maphumulo, Epworth in the then Salisbury, UNISA, and by Fambidzano. Dr Marie-Louise Martin was for some years a principal of the Kimbanguist theological school in Zaire (ibid., 34).

In his study of the message of the AICs (as his primary interlocutors) when speaking for themselves on transformative theological education thus far, the author developed basic curriculum highlights or study areas that could be covered for a decolonised and transformative theological education. An AIC leader who directed Khanya Institute, Bishop Makhubu (1991:270) warned that the AICs' curriculum (in their institution) was brought to the level of the understanding of the person with little formal education. The aim of the curriculum is to arm the students with adequate knowledge and skills. He advised that the areas to be covered are; Biblical Studies, Church History, Christian ethics, Christian education, African religion, homiletics, and administration. The author also noted that they want to promote theological reflection at grass-roots level through Spiritual Churches Research and Theological Training (SCRTTI). Lastly, from the author's secondary interlocutors, he noted Daneel's (1987:164) warning on a relevant AICs' curriculum when he said; "In-service includes cooperate religious activities such as preaching, fasting, prayer groups, parish visiting, proselytising campaigns and disciplinary sessions in council sessions, biblical instruction, and church doctrines. Others render service to the congregation under the supervision of the local leader".

The author's mental trajectory on this curriculum project was that he foregrounded Africa and Southern Africa in particular. He, therefore, placed Africa at the center, not centered Europe in Africa as a European outpost in terms of theological education curriculum. Even on the course titles, he tried to avoid the influence of the global north especially on course titles that were conceived during the pre-modern period in Germany as a result of the impact of enlightenment (Bosch, 1991:490). This was not completely avoided, however, because a curriculum though decolonised, should be in dialogue or contestation with global spaces including the global north. The author also accepted to be influenced by two approaches to curriculum theory and practices which are; curriculum as context and curriculum as praxis. The end-state is to offer a decolonised theological education curriculum that seeks, in the words of De Beer \& Van Niekerk (2017:215), "to offer education that will appropriately prepare students with both the consciousness and abilities to contribute critically, (de)constructively and innovatively to the socioeconomic, political, environmental, spiritual and spatial wellbeing of individuals, communities, organisations and regions in which they are required to serve".

Having listened to the collective message from the AICs as his primary interlocutors, the author therefore, deduced the following curriculum highlights or study areas to be covered; 
From the AICs' ministry praxis in this article, one could deduct a course in the area of ministry studies with content that introduces students to the whole range of pastoral work; management of a congregation, homiletic, liturgy, counseling, caring, house visits, hospital ministry, etc. from African cultural perspective. Church management and financial administration form part of this package. Outreach community programmes for caring for the needy are addressed. President Motsogi, an AIC leader of the New Ethiopian Episcopal Church in South Africa, reasoned that theological education should concentrate on spiritual matters and investigate ways of avoiding conflict between congregations and their leaders (1997; cf. Masuku, 1998:405).

When one studies the efforts of the AICs towards ecumenism among themselves and other denominations, it becomes important to develop a course in this field, ecumenical studies. The course content could address the history of ecumenical movements (including inter-AICs relations) globally with special focus on Africa. AICs demonstrated great interest in their desire for ecumenism through various attempts as seen in this article. Though they are infested with divisions, there is a need to drive the agenda on unity and to unify the divisions and breakaways. Thus, Rev. Mangena Mokone (Ngada \& Mofokeng, 2001:5) who broke away from the Methodist Church in 1892, his principal aim and concern was to; "unite the various groups that had already broken away in order to form one united black church, The Ethiopian Church". This forms the ground for President Motsogi, an AIC leader in the New Ethiopian Episcopal Church in South Africa to "emphasise the need for ecumenism as a part of the theological curriculum" (Masuku, 1998:405).

The AICs' position on the relationship between Christian and African theology was highlighted. A course could be built on this. The content could critically focus on the relationship between both the Christian and African theology concepts. In the words of Ngada and Mofokeng (1998:xii), the AICs "wish to proclaim Christ to the world in an African way, the Christ who died and rose again for the indigenous people of Africa too". Rev. M. Mokone (Ngada \& Mofokeng, 2001:5) "wanted to consolidate the splinter groups into a truly African Church...". He dreamt of a united black church, The Ethiopian Church.

The element of holistic healing ministry by the AICs became apparent in this article. A course with a content that critically discusses bolistic ministry praxis from an African cultural perspective could be developed. The AIC takes the ministry of healing seriously. In the expression of Ngada and Mofokeng (2001:32), "healing of every kind is practised in our churches, not only physical healing. God saves or heals the body, the soul, the society and even the land. God heals relationships between people, including our relationship with our ancestors. God can also heal us when we have been possessed by an evil spirit". He emphasises the need for a ho- 
listic healing ministry that aims to restore one's health from all aspects, physically, spiritually and other possible means. Pobee and Ositelu (1998:49) are therefore correct to point out that ministry in Africa will be judged deficient if it does not treat healing as a function of religion.

AICs' position on public life demonstrated itself in this article. A course could thus be constructed in this field, church and public life. The content could look into the dynamics of church and society. This should address justice in society from all sectors of life. AICs have demonstrated an interest in social justice. Their friction with the British government in the beginning of the 20th century is well documented. This is clear in the words of Ngada and Mofokeng (2001:6) when they stated; "These new churches were saying that they would not rest until Africans were freed from the hardships of British rule". Ngada and Mofokeng (ibid., 51) referring to the AICs role during the political injustice in apartheid SA, added that "during times of great violence, they were directly involved in caring for the victims, comforting the bereaved, and helping those who had been orphaned. It was the leaders of our churches who became the symbols of hope for the hopeless".

A course in the field of new religious movements, in the light of the fact that the AICs are becoming an important factor in theology becomes a necessity. The course content looks at the AICs and other emerging religious movements, their background, relation, origin, development, theology and their impact on contemporary Christianity with special reference to Africa.

\section{Conclusion}

The Western type of theological education fails to address the deeply religious, spiritual and emotional needs of the AICs. They discarded these traditional ways of handling these gaps without providing an alternative. The AICs are swelling in membership because of the people who approach them whenever they are confronted by these traditional realities of life. Relevant theological education should start by addressing the basic concepts and the understanding of God (Kealotswe, 2013:437).

Theological education as a world phenomenon should recognise the various theologies that are emerging all over the world. As long as they are biblical and scriptural, they should be recognised without using the Western model of theological education as a yard stick. Currently, in Africa, theological education is for the AICs an academic prestige while ministerial training for the AICs is from divine calling and expression rather than theory (ibid., 439). The Western type of theological education as a product of Western Enlightenment separates epistemology from ontology and ethics. The AICs' agenda on theological education offered a practical alternative. Historic churches should, therefore, refrain from applying their notae ecclesiae as a yard stick to judge and impose on others. The time has come for 
historic churches to apply what Pobee and Ositelu (1998:39) called the three cornerstones of religion which are; belief, ritual, and religious experience instead of their notae ecclesiae.

\section{References}

Bosch, D.J. 1991. Transforming Mission: Paradigm Shifts in Theology of Mission. Maryknoll: Orbis Books.

Burgess, H.W. 1975. An Invitation to Religious Education. Birmingham, Alabama: Religious Education Press.

Chakanza, J.C. 1991. African Independent Churches in the University of Malawi, Central Africa, 1976-89, in The Handbook of Theological Education in Africa. Great Britain, WCC.

Cochrane, J.R. 1996. The Contextualisation of Theological Education. Bulletin of Contextual Theology, 3(3), 1-9.

Daneel, M.L. 1987. Quest for belonging: Introduction to a study of African Independent Churches. Gweru. Mambo Press.

Daneel, M.L. 2000. General Introduction. Missonalia, 28 (2/3), i-xviii.

De Beer, S.F. \& Van Niekerk, A.S., 2017, 'Transforming curricula into the next century: Doing theology collaboratively with local communities', in 'Theology at the University of Pretoria - 100 years: (1917-2017) Past, present and future', Verbum et Ecclesia, suppl. 2, 38(4), a1683. ttps://doi.org/10.4102/ve.v38i4.1683.

Dlamini, I. 1991. Faith Bible School for Independent Churches in Swaziland, in The Handbook of Theological Education in Africa. Great Britain, WCC.

De Gruchy, J. 1996. Renewal out of Africa. A report on the African consultation on the viability of ecumenical theological formation. Bulletin for Contextual Theology, 3(3), $10-14$.

Ekeya, B.J. 1990. Theological education for women in the Roman Catholic Church: A Kenyan case, in Theological Education in Africa: Quo Vadimus. Asempa Publishers.

Kealotswe, 0. 2013. Theological Education in the African Independent Churches in Botswana, in The Handbook of Theological Education in Africa. Great Britain, WCC.

Makhubu, P. 1991. The Programme of Khanya African Independent Churches Theological and Research Institute, in Ministry in Partnership with African Independent Churches. Indiana: Mennonite Board of Missions.

Makhulu, W.P.K. 1999. The future and place of African Independent Churches in the new South Africa, in Hearing the AIC-Voice. UNISA, Pretoria.

Makofane, K.M. 2019. The African Initiated Churches as an embodiment of the moratorium debate: Lessons for the Evangelical Lutheran Church in Southern Africa, Central Diocese. Missionalia, 47(1), 126-147.

Mala, S.B. 1991. African Instituted Churches in Nigeria: The Quest for unity, education and identity, in Ministry in partnership with African Independent Churches. Indiana: Mennonite Board of Missions. 
Maluleke, T.S. 1994. Restructuring Theological Education in South Africa. Unpublished Paper read at the annual General meeting of the Institute for Contextual Theology (ICT). Braamfontein, 21 June.

Masuku, M.T. 1998. Rev J.L. Rammala: A case study of an African Missionary. Masters dissertation. UNISA.

Masuku, M.T. 1996. African Initiated Churches: Christian Partners or Antagonists? Missionalia, 24(3), 441-455.

Masuku, M.T. 1998. Listening to the forgotten voice: Some views of AIC leaders on theological education. Missionalia, 26(3), 392-411.

Mijoga, H.B.P. 2000. Separate but Same Gospel: Preaching in African Instituted Churches in Southern Malawi. Blantyre: Christian Literature Association in Malawi.

Milumba, M. 2016. Partnership Praxis and Development? A Theological Assessment of the Discourse and Practice of Partnerships among African Initiated Churches in the Post-Apartheid South Africa. MTh dissertation: University of Kwazulu Natal.

Molisiwa, S. 1999. The social impact of the AICs with special reference to illiteracy, poverty and exploitation of their people, in Hearing the AIC-Voice. UNISA, Pretoria.

Molobi, M.S. 2000. AICs as interlocutors for Black Theology in South Africa. MTh dissertation UNISA: Pretoria.

Molobi, V. 2006. The AICs and theological training with special reference to the St John's Apostolic Faith Mission Church of Ma Nku'. Studia Historiae Ecclesiasticae, XXXII, (3), 33-52.

Molobi, M.V. 2010. African, Black and AIC Theologies as the Main Historical Sources for an African Church. Scriptura, 105: 494-506.

Molobi, M.V. 2011. The ecumenical vision of the Organization of African Independent Churches

from an educational perspective. Studia Historiae Ecclesiasticae, 37(1), 1-9.

Molobi, M.V. 2012. The relationship between the WCC and OAIC: An assessment of mutual influence on ecumenical praxis. Studia Historiae Ecclesiasticae, 38(2), 101-118.

Molobi, M.V. 2013. The Historical Voices of the African Independent Churches. Studia Historiae Ecclessisticae, 39(1), 155-167.

Moran, G. 1983. Religious Education development: Images for the future. Minneapolis Minn: Winston Press.

Moremi, M. M. 1991. African Independent Churches and their involvement in the changing situation in South Africa, in Ministry in Partnership with African Independent Churches. Mennonite Board of Missions.

Mulemfo, M.M. 1997. An African Missionary in return: Reflections on a visit to Sweden. Missionalia, 25(1), 100-123.

Muller, R. 2017. Constructing separatism in South Africa's racially charged religiosity: 20th century Afrikaner discourses on African Initiated Christianity. Religion Compass, 11(1-2).

Neill, S. 1954. Survey of the training of ministry in Africa, Part 2. London and New York: International Missionary Council.

Ngada, N.H. 1999. Transformation of theology in the African Indigenous Churches, in Hearing the AIC-Voice. UNISA: Pretoria. 
Ngada, N.H. \& Mofokeng K.E. 2001. African Christian Witness: African Indigenous Churches. Pietermaritzburg: Cluster Publications.

Nongogo, N.S. 1999. AICs' reaction to past discrimination and their reconciliatory role in the new South Africa, in Hearing the AIC-Voice. UNISA: Pretoria.

Oduro, T. 2013. Theological Education in African Independent Churches: A Plethora of Pedagogies, in The Handbook of Theological Education in Africa. Great Britain, WCC.

Padwick, T.J. 2018. 'The Spirit Alone': Writing the Oral Theology of a Kenyan Independent Church. Transformation, 35(1), 15-29.

Pederson, L. 1980. Missionary Go Home? Chicago: Moody Bible Institute.

Pobee, J.S. \& Ositelu, G. 1998. African Initiative in Christianity: The growth, gifts and diversities of indigenous African churches: A challenge to the ecumenical movement. Geneva: WCC.

Reimer, J. 2007. They come with a message: The gospel of missionaries from the Two-Third World in old Europe. Missionalia, 35(2), 3-17.

Richardson, N. 2007. Ministerial training and theological education in the Methodist Church of Southern Africa: The road ahead. Missionalia, 35(2), 131-152.

Saayman, W. 2013. Mission as theological education: Is Christian mission history coming full circle. Missionalia, 40(3), 133-145.

Shank, D.A. 1991. Ministry in Partnership with African Independent Churches: papers presented at the Conference on Ministry in Partnership with African Independent Churches, July 1989 Kinshasa, Zaire. Kinshasa.

Sundkler, B. 1960. The Christian Ministry in Africa. London: SCM Press.

Theron, P.F. 1993. Theological training in the Context of Africa: A Freirian model for social Transformation as part of the missionary calling of the church. DTh-Thesis, University of Pretoria.

Tshelane, S.S. 1999. The quest for unity and structure inside and between the AIC groups, in Hearing the AIC-Voice. UNISA: Pretoria.

Wepener, C., 2015, 'African therapy for a fractured world (view): The life of founder bishop Johannes Richmond and the invention of tradition and group cohesion in an African Initiated Church', HTS Teologiese Studies/ Theological Studies 71(1), Art. \#2900, 9 pages. http:// dx.doi.org/10.4102/hts. v71i1.2900. 